\section{Infiltration and Erosion Studies on Pinyon-Juniper Conversion Sites in Southern $\mathrm{Utah}^{1}$}

\author{
GERALD F. GIFFORD, GERALD WILLIAMS, AND \\ GEORGE B. COLTHARP
}

Assistant Professor, Graduate Research Assistant, and Assistant Professor (Range Watershed Science) respectively, Range Science Department, Utah State University, Logan.

\section{Highlight}

Infiltration and sediment data from small-plot studies (325 infiltrometer plots) utilizing high intensity simulated rainfall indicate that areas cleared of pinyon-juniper trees and seeded to grass in southern Utah generally show no consistent decrease or increase in sediment yields or infiltration rates at a given point. Of 14 sites studied, four indicated decreased infiltration rates and two indicated increased infiltration rates during one or more time intervals at specific points on the treated areas; one site had significantly less sediment yield and two sites had significantly higher sediment yields from points on the treated areas. These results nearly parallel those obtained during similar studies of 14 pinyon-juniper sites in central Utah.

${ }^{1}$ This study was in cooperation with the Bureau of Land Management, Contract No. 14-11-0008-2837. Their support is gratefully acknowledged. Journal Paper No. 944, Utah Agricultural Experiment Station, Logan, Utah. Received July 25, 1969; accepted for publication November 8, 1969.
Millions of acres of pinyonjuniper lands are located throughout the western United States. Within the past 20 years, numerous large-scale pinyon-juniper conversion programs have been initiated. These programs have created a demand for increased knowledge concerning range and watershed values as influenced by vegetation manipulations in this type.

The authors, in a recently completed infiltrometer study of 11 chained pinyon-juniper sites in central Utah, have shown that conversion of pinyon-juniper to grassland (regardless of length of time since treatment) does not necessarily increase or decrease infiltration rates or always reduce sediment yields from a given point on treated areas (Williams, Gifford, and Coltharp, 1969).

In another study, Gifford and Tew (1969) have found increased permeabilities of surface soils from a chained and windrowed site in southwestern Utah 6 months following treatment. Soils from another site in southeastern Utah (same study) showed a similar trend, although it was not statistically significant. Mechanical disturbance associated with double chaining with debris in place did not significantly increase surface soil permeabilities at either site. 
Table 1. Brief description of study sites $^{1}$ near Blanding, Utah.

\begin{tabular}{|c|c|c|c|c|}
\hline & & Percent cover ${ }^{4}$ & Annual ${ }^{5}$ & \\
\hline Project $^{2}$ & $\begin{array}{c}\text { Date } \\
\text { seeded }^{3}\end{array}$ & $\begin{array}{l}\text { Un- } \\
\text { treated Treated }\end{array}$ & $\begin{array}{l}\text { tation } \\
\text { (inches) }\end{array}$ & $\begin{array}{l}\text { Grazing } \\
\text { history }\end{array}$ \\
\hline
\end{tabular}

1. Peters Point

Location \#1

$1964 \quad 0-6 \quad 3-18 \quad 14 \quad$ Negligible summer use

Double chained

before treatment. After

and debris in place

Location \#2

Double chained

and debris in place

2. Brush Basin

Double chained

and debris in placc

3. Alkali Ridge

Double chained

1960

$0-6 \quad 0-38$

14

treatment light summer use except heavy use around water.

and debris in place

4. Job \#149

1965

$0-4$

$0-25$

11-12

Same as \# 1

Double chained

and debris in place

5. Utah State University

study sites

Location \#1

Double chained

1967 $0 \quad 0 \quad 11-12$ No grazing since

treatment

and debris in place

Location \#2

Double chained

1967

0

0

11-12

No grazing since treatment gible use, after treatment stocked at 5 acre/ AUM.

and windrowed

${ }^{1}$ Elevations of all sites were between 6,000 and 7,000 feet above sea level.

${ }^{2}$ Windrowed sites were drill seeded and non windrowed sites were broadcast seeded.

${ }^{3}$ Seeded primarily to crested wheatgrass at 6-8 lbs./acre in fall unless otherwise indicated.

4 Percent plant cover on infiltrometer plots (excludes canopy coverage of pinyon-juniper on untreated plots).

"Annual precipitation values taken from the annual normal precipitation map for the State of Utah (1931-1960).

Little change in surface runoff and soil moisture patterns has been found following clearing of pinyonjuniper in Arizona (Skau, 1964; Brown, 1965; Collings and Myrick, 1966).

The objective of this project was to study infiltration rates and sediment production at given points on converted and nearby untreated pinyon-juniper sites in southern Utah.

\section{Methods}

A Rocky Mountain infiltrometer (Dortignac, 1951) was utilized to simulate high intensity (3 inches/ hr or greater) rainfall on plots ap- lecting total runoff plus sediment from each plot, mixing thoroughly, and finally obtaining a l-quart sample. The water was then evaporated off, sediment oven-dried, and sample weights converted to tons per acre.

Soils in the study sites were derived from colluvium, alluvium, residium, and eolian of mainly sedimentary and volcanic rocks (Milford area) and sandstones and shales (Blanding area).

\section{Results and Discussion \\ Pinyon-Juniper Sites Near Blanding, Utah}

Table 3 shows mean infiltration rates (inches/hr) during specified time intervals and Figure 1 denotes relative differences in sediment production from treated and nearby untreated conditions on six pinyonjuniper sites studied near Blanding, Utah. As noted from Tablc 1, age of treatment varied from 1 to 8 years.

U.S.U. (Utah State University) Study Site.-No significant differences in infiltration rates are indicated between treated and untreated conditions during any time interval on the area which had been double chained with debris left in place (item 1, Table 3). However, on the area with debris windrowed, the untreated area showed significantly higher infiltration rates during the time interval 8 to 18 minutes following start of simulated rainfall. There were no significant differences between treated and untreated areas with regard to sediment production.

Area 149, Brush Basin, Peters Point \#1, and Peters Point \#2.No significant differences between treated and untreated conditions are indicated for either infiltration rates (Table 3) or sediment yields (Fig. 1).

Alkali Ridge.-At the Alkali Ridge site, the following four cxclosures were located within the treated area: (1) everything excluded, (2) rabbits only, (3) deer only, and (4) deer and rabbits only. As noted in Table 3, infiltration 
Table 2. Brief description of study sites $^{1}$ near Milford, Utah.

\begin{tabular}{|c|c|c|c|}
\hline & & Percent cover Annual $^{5}$ & \\
\hline Project $^{2}$ & $\begin{array}{r}\text { Date } \\
\text { seeded }^{3}\end{array}$ & $\begin{array}{c}\text { Un- } \\
\text { treated Treated (inches) }\end{array}$ & $\begin{array}{l}\text { Grazing } \\
\text { history }\end{array}$ \\
\hline
\end{tabular}

1. Indian Peaks

Location \# 1

Chained and

$1964^{3 a} \quad 0-10 \quad 0-20 \quad 10$

windrowed

Location \#2

$1960^{\text {sb }} \quad 0-10 \quad 0-35$

11

Chained and

windrowed

Location \#3

$\begin{array}{lll}0 & 0-30 & 12\end{array}$

Double chained

and debris in

place

Location \#4

Chained and

windrowed

2. New Arrowhead

$\begin{array}{ccc}1962- & 0 & 2-76 \\ 64^{3 \mathrm{~b}} & & \end{array}$

15

mine. Chained

and windrowed

\section{$1961^{3 a} \quad 0-1 \quad 0-66 \quad 11 \quad$ Same as \# 1}

Grazed in spring, summer and fall before treatment grazed in late spring and early summer in a rotation system after treatment.

Grazed in spring, summer and fall before treatment grazed in mid and late summer in rotation system after treatment.

(and

rates were significantly greater after approximately 6 minutes of simulated rainfall in the deer-only exclosure and on the treated area (outside exclosures) after 8 minutes. Similarly, in the exclosure excluding everything, a significantly higher infiltration rate was observed during the 8 to 23-minute time interval. A significantly higher infiltration rate was indicated for the deer-and-rabbit-only exclosures during the time interval 18 to 23 minutes. No significant infiltration rate differences were noted between treated and untreated conditions as related to the rabbits-only exclosure, though the trend was the same as noted above.

As noted in Figure 1, sediment yields are significantly greater from untreated conditions than from the deer-and-rabbits-only exclosure and the everything-excluded exclosure. Differences were not significant between the other treated vs. untreated conditions, though the untreated condition appeared to yield more sediment in each case.

\section{Pinyon-Juniper Sites Near Milford, Utah}

Table 4 shows mean infiltration rates during specified time intervals and Figure 2 denotes relative differences in sediment production from treated and untreated conditions on eight sites near Milford, Utah. As noted from Table 2, age of treatment varied from 1 to 8 years.

Arrowhead Mine and Indian Peaks \#1,2,3, and 4.-As noted in Table 4 the infiltration rate during the 3 to 4 minute time interval on Indian Peaks \#1 site was significantly greater on the untreated area. No significant differences in infiltration rates between treated and untreated conditions were demonstrated for any other time intervals on Indian Peaks numbers 1, 2, 3 and 4, or Arrowhead Mine. Also, as noted in Figure 2, there were no significant differences in sediment production between treated and untreated conditions on any of the above areas.

U.S.U.Study Site.-No significant differences in infiltration rates are 
Table 3. Mean infiltration rates (inches/hr.) during specified time intervals (minutes) on various pinyon-juniper sites near Blanding, Utah.

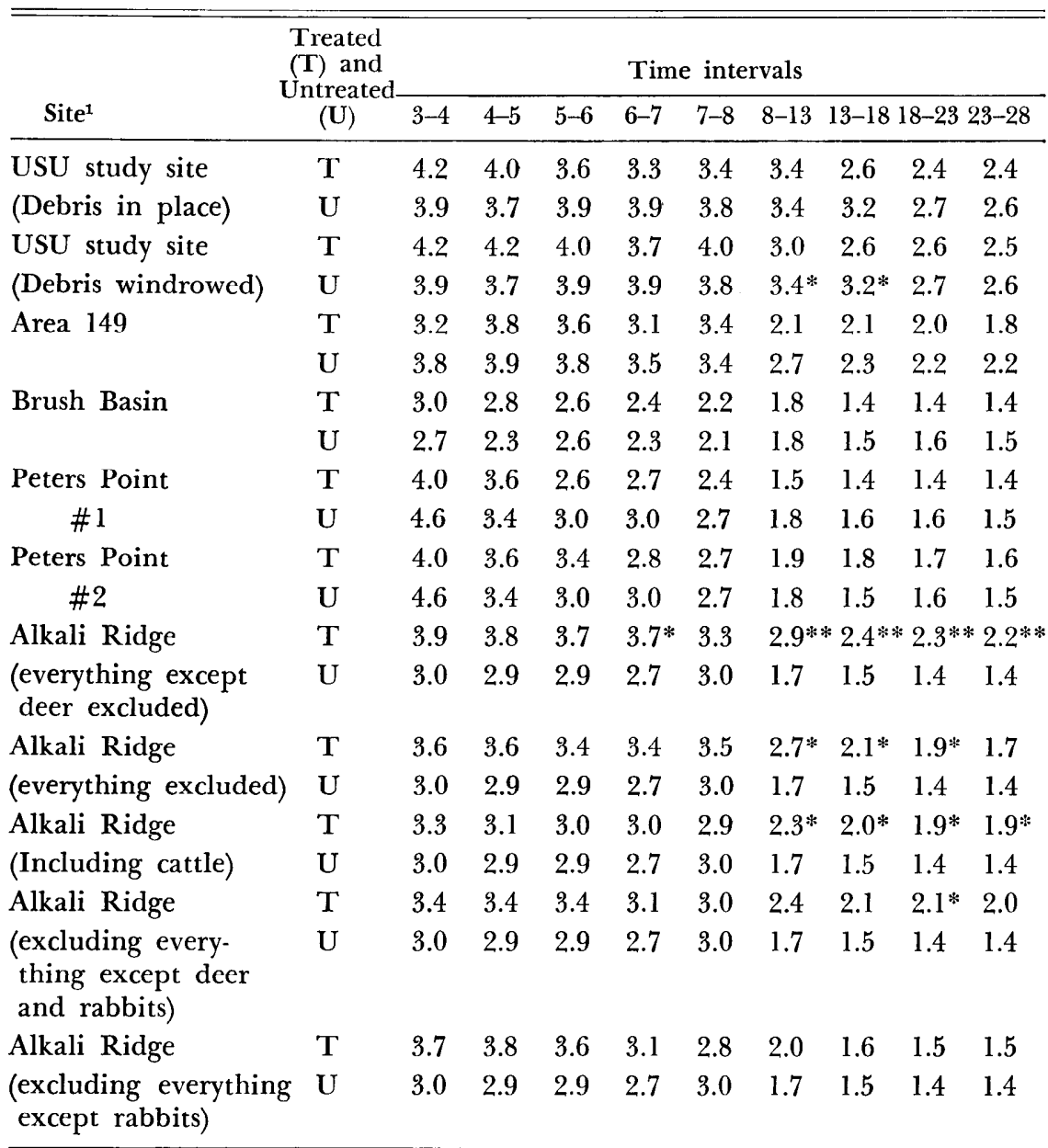

${ }^{I}$ See Table 1 for a brief description of sites.

* Significantly larger at $5 \%$ level of probability than other value in pair.

** Significantly larger at $1 \%$ level of probability than other value in pair.

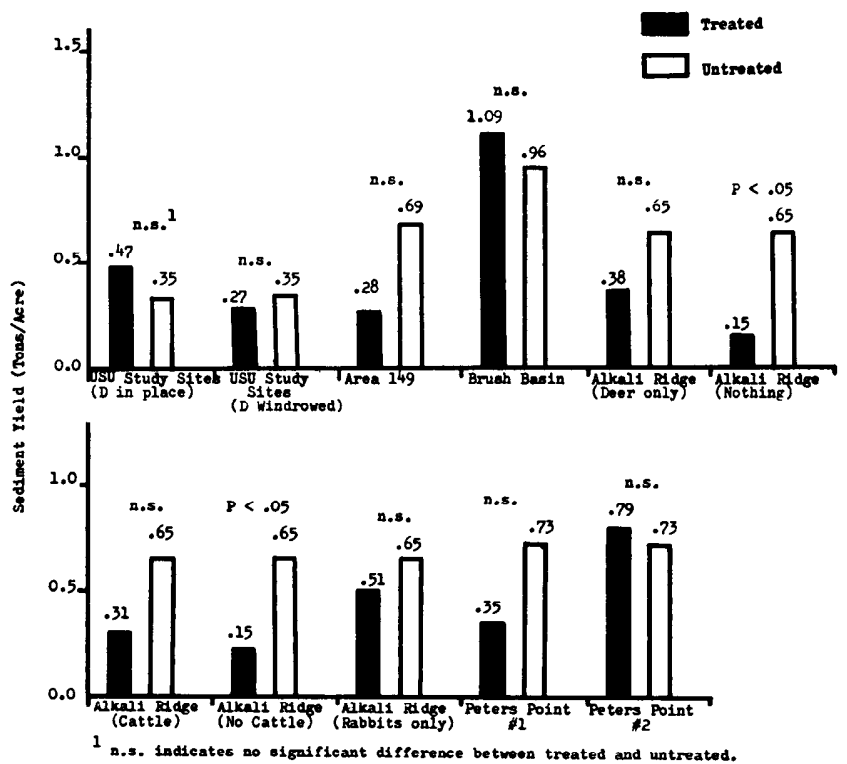

Fis. 1. Relative sediment yields from six P-J sites near Blanding, Utah. shown (Table 4) between the area which had been double chained with debris left in place and the untreated area. The area with windrowed debris had a significantly lower infiltration rate than the untreated area during the time interval 13 to 28 minutes following start of simulated rainfall. This probably resulted because vegetative cover was lacking on the newly windrowed area.

Significantly more scdiment was moved from the windrowed area than from untreated areas. Sediment yields from the chained with debris in place area were similar to those from untreated areas.

Jockey's.-The treated area showed significantly higher infiltration rates for all time intervals during simulated rainfall. In addition, and somewhat unexpectedly, significantly higher sediment was yielded from the treated area.

Indian Creek Conservation Area. -In contrast to the Jockcy's area, the untreated area shows significantly higher infiltration rates during the 5 to 6 -minute time interval and all time intervals after $8 \mathrm{~min}$ utes of simulated rainfall. No significant differences in sediment yields were apparent between treated and untreated conditions.

\section{Conclusions}

Infiltration and sediment data collected with a Rocky Mountain infiltrometer on 14 sites in southern Utah indicate that areas cleared of pinyon-juniper trees and seeded to grass show no consistent decrease or increase in sediment yields or infiltration rates at a given point. Of 14 sites studied, four (all with debris windrowed) indicated decreased infiltration rates during one or more time intervals at points on the treated portion. Two sites indicated increased infiltration rates during one or more time intervals at points on the treated area. Eight sites showed no significant differences in infiltration rates between points for the treated and untreated conditions. As for sediment yields, one site had significantly less yield from 


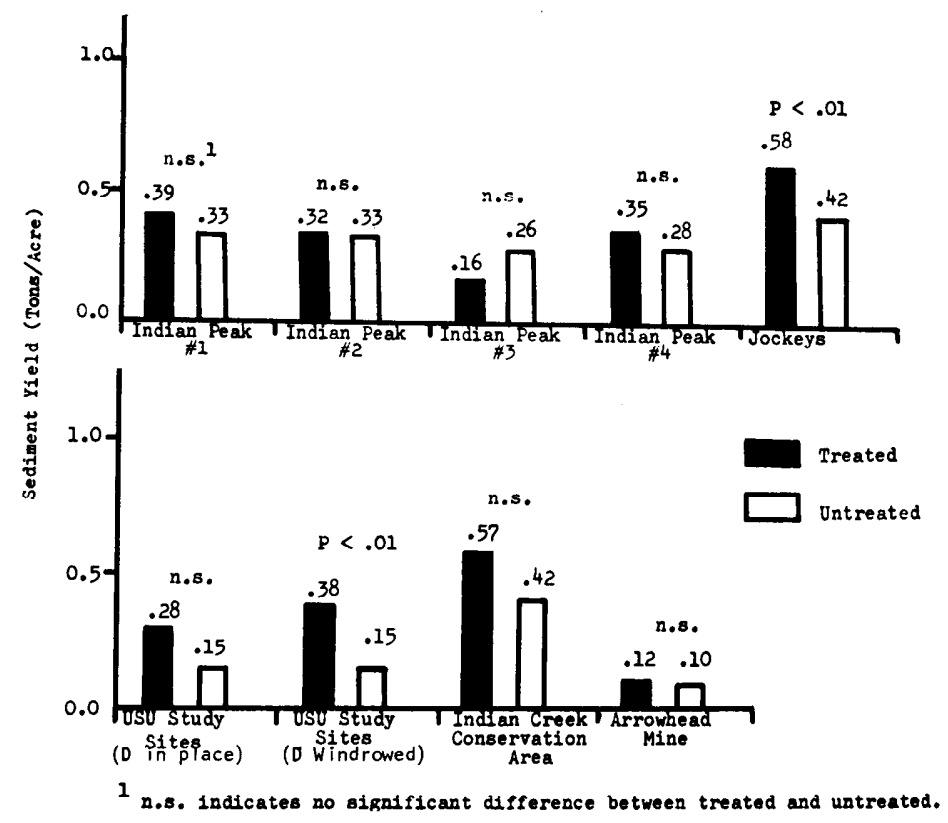

Fig. 2. Relative sediment yields from eight P-J sites near Milford, Utah.

points on the treated area and two sites had significantly higher sediment yields from points on the treated areas.

These findings are similar to the

results recently reported from study of 14 sites in central Utah (Williams et al., 1969). After study of 28 treated pinyon-juniper sites (of various age since treatment) throughout

Table 4. Mean infiltration rates (inches/hr.) during specified time intervals (minutes) on various pinyon-juniper sites near Milford, Utah.

\begin{tabular}{|c|c|c|c|c|c|c|c|c|c|c|}
\hline \multirow[b]{2}{*}{ Site $^{1}$} & \multirow{2}{*}{$\begin{array}{c}\text { Treated } \\
(T) \text { and } \\
\text { Untreated } \\
(\mathbf{U})\end{array}$} & \multicolumn{9}{|c|}{ Time intervals } \\
\hline & & $3-4$ & $4-5$ & $5-6$ & $6-7$ & $7-8$ & $8-13 \quad 1$ & $13-181$ & $18-23$ & $23-28$ \\
\hline \multirow[t]{2}{*}{ Arrowhead Mine } & $\mathrm{T}$ & 4.0 & 4.0 & 3.2 & 3.0 & 2.7 & 2.8 & 2.6 & 2.5 & 2.5 \\
\hline & $\mathbf{U}$ & 3.6 & 3.6 & 3.5 & 3.1 & 3.7 & 2.7 & 2.6 & 2.3 & 2.4 \\
\hline Indian Peaks & $\mathrm{T}$ & 3.1 & 2.5 & 2.3 & 2.2 & 2.0 & 1.7 & 1.6 & 1.5 & 1.5 \\
\hline \#1 & U & $3.9^{*}$ & 3.2 & 2.7 & 2.2 & 2.2 & 1.8 & 1.7 & 1.6 & 1.6 \\
\hline Indian Peaks & $\mathrm{T}$ & 3.6 & 2.6 & 2.2 & 1.9 & 2.0 & 1.8 & 1.7 & 1.6 & 1.6 \\
\hline \#2 & $\mathrm{U}$ & 4.0 & 3.3 & 2.8 & 2.3 & 1.2 & 1.8 & 1.8 & 1.7 & 1.7 \\
\hline Indian Peaks & $\mathrm{T}$ & 4.2 & 3.9 & 4.8 & 4.4 & 4.3 & 3.9 & 3.8 & 3.7 & 3.9 \\
\hline \#3 & $U$ & 5.4 & 4.9 & 5.1 & 4.9 & 4.7 & 4.2 & 4.0 & 3.9 & 4.0 \\
\hline Indian Peaks & $\mathrm{T}$ & 3.2 & 2.4 & 3.2 & 2.6 & 2.5 & 1.8 & 1.4 & 1.3 & 1.3 \\
\hline \#4 & $\mathrm{U}$ & 4.0 & 3.4 & 3.1 & 2.6 & 2.7 & 2.5 & 2.3 & 2.1 & 2.1 \\
\hline \multirow[t]{2}{*}{ Jockeys } & $\mathrm{T}$ & $4.1 * *$ & $4.1^{* *}$ & $3.0 * *$ & $3.2 * *$ & $3.0 * *$ & $2.9 * *$ & $* 2.8 * *$ & $2.7 * *$ & $* 2.8 * *$ \\
\hline & $\mathrm{U}$ & 2.0 & 1.8 & 1.7 & 1.5 & 1.6 & 1.3 & 1.0 & 1.0 & 1.0 \\
\hline USU study site & $\mathrm{T}$ & 3.1 & 2.6 & 2.4 & 2.2 & 2.2 & 1.6 & 1.6 & 1.5 & 1.5 \\
\hline (Debris in place) & $\mathrm{U}$ & 3.5 & 3.0 & 2.9 & 2.7 & 2.7 & 2.2 & 2.1 & 2.1 & 2.0 \\
\hline USU study site & $\mathrm{T}$ & 2.6 & 2.4 & 2.4 & 2.3 & 2.2 & 1.8 & 1.4 & 1.5 & 1.5 \\
\hline (Windrowed) & $\mathbf{U}$ & 3.5 & 3.0 & 2.9 & 2.7 & 2.7 & 2.2 & $2.1^{*}$ & $2.0^{*}$ & $2.0 *$ \\
\hline Indian Creek Res. & $\mathrm{T}$ & 3.8 & 3.1 & 2.6 & 2.2 & 2.1 & 1.6 & 1.3 & 1.2 & 1.3 \\
\hline Conserv. Area & $\mathbf{U}$ & 3.8 & 3.7 & $3.7^{*}$ & 3.0 & 3.0 & $2.6^{*}$ & $2.2^{*}$ & $2.0^{*}$ & $2.0 *$ \\
\hline
\end{tabular}

${ }^{1}$ See Table 2 for a brief description of sites.

* Significantly larger at $5 \%$ level than other value in pair.

** Significantly larger at $1 \%$ level than other value in pair.
Utah (involving approximately $\mathbf{5 5 0}$ infiltrometer plots), it may be concluded that generally infiltration and erosion rates at a given point have not been particularly affected as a result of treatment practices. If there are treatment effects, they may be either positive or negative.

It is well known that many biotic, edaphic, and climatic variables interact to determine infiltration and erosion rates at a point on given landscapes. All of the above infiltrometer data are being further analyzed to determine those factors important in determining or predicting point infiltration rates and sediment yiclds on pinyon-juniper sites. Such analyses should aid in future predictions of the effect at a given point that certain vegetation conversion practices have on watershed parameters.

\section{Literature Cited}

Brown, H. E. 1965. Preliminary results of cabling Utah juniper, Bcaver Creek Watershed Evaluation Project. In Proceedings, 9th Annual Arizona Watershed Symposium, Tempe, Arizona, Sept. 22, p. 16-21.

Collings, M. R., ANd R. M. Myrick. 1966. Effects of juniper and pinyon eradications on stream flow from Corduroy Creek Basin, Arizona. U.S. Geol. Surv. Prof. Paper 491-B. 12 p.

Gifford, G. F., AND R. K. TEW. 1969. Influence of pinyon-juniper eradication and water quality on permeability of surface soils. Water Resources Res. 5:895-899.

SkAU, C. M. 1964. Soil moisture storage under natural and cleared stands of alligator and Utah juniper in northern Arizona. U.S. Forest Serv., Rocky Mt. Forest \& Range Exp. Sta. Res. Note RM-24. 3 p.

Williams, G., G. F. Gifford, AND G. B. Coltharp. $1969 . \quad$ Infiltrometer studies on treated vs. untreated pinyon-juniper sites in central Utah. J. Range Manage. 22:110-114.

Longmont Seed Co. We Buy \& Sell Western Range Grass \& Legume Seeds 